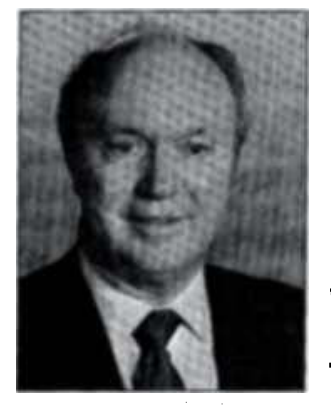

\title{
Water scarcity: the changing California water scene
}

After five consecutive years of drought, it is easy to forget that California faces major long-term - as well as short-term - water problems. With no clearly articulated water policy for California, the drought may foreshadow a water future where urban supplies are rationed, agricultural supplies are severely reduced and the quality of water-based environments is continually threatened, even when rainfall is normal.

The California Department of Water Resources estimates that, in the absence of new facilities or other strategies, the water supply deficit in a normal precipitation year could reach 2 million acre-feet by the year 2010. The state's annual population growth of about 700,000 adds nearly 100,000 acre-feet to the urban water demand each year. Although agricultural water demand is not likely to grow, existing levels of agricultural water use depend on ground water overdraft, a practice which cannot continue indefinitely. Demand for water devoted to environmental amenities such as fish, wildlife, recreation, scenic values and the support of aquatic ecosystems is also increasing.

As surely as drought, deteriorating water quality reduces available supplies. Toxic wastes, salinity and the residues of agricultural chemicals threaten ground water supplies while surface water quality is threatened by agricultural drainage, land-use practices and urban runoff.

Persistent water scarcity, exacerbated by deteriorating water quality, can affect the prosperity and quality of life of all Californians. Adapting to water scarcity will require institutional innovation as well as scientific advancement. New technologies can help only if there are sufficient incentives to employ them effectively. Some facets of the long-term problem cannot be solved technologically. Rather, we must rely on carefully crafted policies that influence the way water is used. A look at some of the more pressing water issues reveals that science, technology, and water institutions and policies are necessary and interrelated components of any lasting solution to our water problems.

- Water conservation. Water consumers in both the urban and agricultural sectors are likely to be under continuing pressure to increase the efficiency with which they use water. The development of new irrigation techniques and water use hardware will help. Simultaneously, however, policies are needed which provide water users with incentives to economize on water use. Arrangements which reward, rather than penalize, those who manage their water carefully will be crucial.

- Ground water banking. Because factors impeding the development of new surface supplies are likely to persist, ground water banking will remain an attractive means for augmenting the state's developed water supplies. But the full potential of water banking cannot be realized unless we find ways to better manage both ground water quality and ground water extractions. New technology can help with the cleanup of contaminated aquifers, but we must also develop new methods of managing land use and industrial chemicals. In addition, acceptable means for managing ground water extractions must be found in order to provide appropriate incentives for the development and use of ground water banks. In the absence of improved management techniques to protect the quality of ground waters and effective systems to govern ground water extractions, the full promise of ground water banking is not likely to be realized.

- Water quality and water reuse. The search for new techniques of managing water quality and new technologies for treating wastewaters must continue. New schemes for reusing degraded water in activities that do not require high quality water must be developed. However, the degradation of water quality often results from a failure of will rather than a failure of technology. Maintaining water quality is a complex task. Sophisticated systems of incentives and policies are necessary to ensure that: 1) reuse possibilities are optimized and 2) the quality of the state's waters is not inadvertently allowed to deteriorate further.

- Managing salt balances. The salinization of soils poses a major threat to California agriculture in both the long- and shortrun. Today's efforts to manage salt buildup only buy time, whether through the use of evaporation ponds, salt storage in the soil profile or reuse of salty water. Ultimately, we must find ways to export salt from basins where it is accumulating or to isolate it absolutely within those basins. The selection of appropriate measures must take into account environmental impacts; some of which are not well understood. The management of salt balances will likely be expensive and funding sources must be identified. Management of salt balances over the long-run is among the most urgent items on the state's water resources agenda.

- Water marketing and water pricing. The recent success of the state's surface water bank in alleviating the current drought demonstrates that market-like water transfers do have a role in managing scarce water resources. Yet many questions regarding the role and form of market-like transfers remain. The impact of transfers on third parties, on local economies and on the social infrastructure in areas of origin are incompletely understood. In addition, we must develop arrangements to ensure that water can be allocated to public uses (such as those to support environmental amenities and fish and wildlife habitat) through market-like institutions.

Beginning almost a century ago, the University of California built a distinguished tradition of education and research in water resources. That tradition continues through the activities of organized research units, such as the Water Resources Center and the Salinity and Drainage Task Force, as well as through the efforts of nearly 400 faculty and extension personnel with professional interests in water resources. But California's modern water problems demand more than traditional approaches. Science and technology alone are insufficient. The political will to select appropriate policies is essential.

The University of California has an important role to play in generating knowledge to support the debates and decisions at the heart of the policy making process. University researchers and extension personnel should continue to advance water science and technology, but the research agenda must also be broadened to address fundamental questions of water policy.

Henry Vaux, Director of the UC Water Resources Center, provided essential background for the preparation of this editorial. 